\title{
A Fiscal Stabilisation Function for the Eurozone
}

The Five Presidents' Report of 2015 called for a macroeconomic stabiliser that would be capable of dealing with asymmetric shocks. A European unemployment benefits scheme (EUBS) is one potential stabilisation mechanism, although other proposals for devising risksharing tools that could be deployed across the eurozone have also been put forward over the years. The following papers, based on a recent Intereconomics conference, explore and compare the advantages and disadvantages of the various schemes entertained. Which one holds the greatest promise of reducing the risk of deep recession? Do such schemes inevitably lead to moral hazard or are there practical safeguards that can be built into their provisions to minimise this risk? Are any of these proposals politically feasible in the near term? This Forum seeks to answer these questions, searching for solutions that can overcome the political resistance to risk sharing in order to secure the economic benefits of risk reduction.

\author{
Reflections on the Euro Area Fiscal Stance \\ Christophe Kamps, European Central Bank, Frankfurt, Germany. \\ Nadine Leiner-Killinger, European Central Bank, Frankfurt, Germany. \\ Jacopo Cimadomo, European Central Bank, Frankfurt, Germany. \\ Sebastian Hauptmeier, European Central Bank, Frankfurt, Germany.
}

Fiscal Rules and the Scope for Risk Sharing

lain Begg, European Institute, London School of Economics and Political Science, UK.

The Stabilising Role of US Federal Fiscal Institutions - What Lessons for the Euro Area?

Cinzia Alcidi, Centre for European Policy Studies, Brussels, Belgium.

Gilles Thirion, Centre for European Policy Studies, Brussels, Belgium.

What the EU Can Learn from the American Experience with Unemployment Insurance

Suzanne Simonetta, Department of Labor, Washington DC, USA.

European Fiscal Governance and Cyclical Stabilisation: Searching for a Lasting Arrangement

Nicolas Carnot, European Commission, Brussels, Belgium.

Risk Reduction, Risk Sharing and Moral Hazard: A Vaccination Metaphor

Frank Vandenbroucke, University of Amsterdam, Netherlands.

Ten Lessons from a Decade of Debating an EUBS: Robust Findings, Popular Myths and Remaining Dilemmas

Sebastian Dullien, HTW Berlin - University of Applied Sciences, Germany; and European Council on Foreign Relations, Berlin, Germany. 